\title{
PLINIJ STAREJŠI O GRŠKEM SLIKARSTVU IN NJEGOVEM NAJPOMEMBNEJSEEM PREDSTAVNIKU, APELU IZ KOLOFONA PRI EFEZU
}

Ključne besede: Plinij starejši, Naravoslovje, Naturalis Historia, umetnostnozgodovinski viri, grško slikarstvo, Apel, Aleksander Veliki

Med vsemi zvrstmi likovnih umetnosti, ki jih je Plinij starejši vključil v svoje enciklopedično delo Naravoslovje (umetna obrt, kiparstvo v bronu, slikarstvo, terakotna plastika, kiparstvo v marmorju, arhitektura, mozaiki in gliptika), se je skozi zgodovino najslabše godilo ravno slikarstvu. Zaradi narave materiala smo izgubili tako rekoč vse grške mojstrovine. Kako velika je ta izguba, nam ni povsem v zavesti. Verjetno je še veliko večja, kot si predstavljamo, saj so Grki med vsemi likovnimi zvrstmi - in po muzejih si lahko ogledamo občudovanja vredne originale - najbolj cenili ravno slikarstvo. Zato si velja, med vsemi Plinijevimi poglavji iz zgodovine antičnih umetnosti, natančno ogledati ravno ekskurz o grškem slikarstvu. ${ }^{46}$

Poleg Plinija starejšega so posamezne podatke o grškem slikarstvu zapisali tudi nekateri drugi grško-rimski avtorji, velikokrat pa priskočita na pomoč papirologija in epigrafika. Začetno pot grškega slikarstva lahko z veliko gotovostjo razberemo iz sočasnega vaznega slikarstva, ki je pomemben sekundarni vir tudi za klasične umetnike 5. stol. pr. Kr. Izjemnega pomena so izvirna dela poznoklasične slikarske umetnosti, zlasti odkritje poslikanih grobnic v antični Makedoniji. Tako lahko posameznim slikarjem 4. stol. pr.

$46 \mathrm{~V}$ primerjavi z drugimi umetnostnimi zvrstmi je Plinij slikarstvu namenil kar tri četrtine 35. knjige, kar je veliko več kot pri drugih knjigah. Tudi iz tega lahko sklepamo, da je bilo slikarstvo med vsemi likovnimi umetnostmi najvišje vrednoteno. 
Kr. celo pripišemo originale! Veliko izpovedno moč imajo tudi stenske poslikave in mozaiki iz rimskega časa, čeprav so le daljni odsev ikonografskih kompozicij in tehničnih rešitev znamenitih grških zgledov.

Plinij starejši se je v svojem pregledu grškega slikarstva zgledoval po umetnostnozgodovinskih spisih Ksenokrata iz Aten, kiparja Lizipove šole in pisca, ki je deloval na začetku 3. stol. pr. Kr. Ksenokratovo pisanje je obogatil s podatki iz slikarskih traktatov 5. in 4. stol. pr. Kr. ter deli Durisa s Samosa (na prehodu iz 4. v3. stol. pr. Kr.) in Antigona iz Karista (začetek 3. stol. pr. Kr.). Iz tega sledi Plinijev koncept pregleda grškega slikarstva: Ksenokratov razvojni lok grške umetnosti $\mathrm{z}$ vidika sosledja iznajdb, ki težijo $\mathrm{k}$ vedno večji dovršenosti tehnike in $\mathrm{k}$ naturalizmu, prepleta $\mathrm{z}$ Durisovimi podatki iz življenja znamenitih umetnikov in anekdotami ter nekaterimi Antigonovimi popravki predhodnih avtorjev. Po Ksenokratu je vrhunec slikarske evolucije dosežen z Apelom in tudi Plinij zapiše, da je Apel največji grški slikar vseh časov $(35,79)$.

Ekskurz o slikarstvu $(35,2-150)$ Plinij začne z vprašanjem izvora likovne zvrsti. Predstavitvi prvih iznajdb sledi neprekinjen lok slikarjev klasične dobe 5. stol. pr. Kr. in slikarskih šol 4. stol. pr. Kr., vse do Apela in njegovih sodobnikov iz časa Aleksandra Velikega in diadohov. Plinij na tem mestu, okoli leta 300 pr. Kr., svoj pregled konča. Temu jedru sicer doda še nekaj umetnikov iz srednjega in poznega helenizma, zlasti predstavnikov neoaticizma (Heraklida iz Makedonije in Metrodora iz Aten, oba iz prve polovice 2. stol. pr. Kr., ter Timomaha iz Bizanca, iz sredine 1. stol. pr. Kr.) in osem imen rimskih umetnikov, vendar je njegova pozornost usmerjena na razvojni lok grškega slikarstva od arhaične do poznoklasične dobe (oziroma začetnega helenizma).

V našem prispevku bomo sledili Plinijevi zasnovi. Tako bomo najprej omenili avtorjev pogled na izvor likovne zvrsti v arhaični dobi, nadalje bomo predstavili sosledje iznajdb v klasičnem obdobju in slikarske šole 4 . stol. pr. Kr., končali pa bomo z analizo Apelovega opusa, ki ga je Plinij starejši postavil na sam vrh grške slikarske umetnosti. 


\section{Izvor slikarstva $\mathbf{v}$ arhaični dobi}

Potem ko Plinij starejši v uvodnih poglavjih predstavi najpomembnejšo zvrst likovnih umetnosti, to je slikarstvo, in jo moralno ovrednoti (35, $2-14$ ), se takoj zatem povpraša o njenem izvoru in prvih odkritjih, ki so ji postavila temelje $(35,15-16)$.

Egipčani so trdili, da je slikarstvo njihova iznajdba, toda Plinij starejši s tem ne soglaša. Prepričan je, da so ga odkrili Grki, bodisi v Sikionu bodisi v Korintu $(35,15)$. Dodelitev primata le enemu od obeh mest ni lahka, saj sta obe na Peloponezu in sta med seboj oddaljeni le kakih $20 \mathrm{~km}$. Prav tako sta bili že od arhaične dobe dalje obe pomembna slikarska centra. ${ }^{1}$ Pri tem pa se Plinij starejši $(35,54-55)$ ne strinja s svojimi grškimi viri, ki postavljajo prve slikarje šele v čas 90 . olimpiade, to je med letoma 420 in 417 pr. Kr. Rimski polihistor namreč šteje za slikarstvo že najstarejše likovne poskuse, grški avtorji pa postavljajo na začetek umetnike iz časa, ko je slikarstvo že razvita in avtonomna likovna zvrst. V prid svoji tezi navaja Plinij dva dokaza. Prvič $(35,54)$, Fidija in njegov brat Panajnos sta datirana v čas 83. olimpiade (448-445 pr. Kr.). Drugič $(35,55)$, Bularhovo sliko z motivom Bitke med Magnezijci in Himerci (ali Efežani) je za visoko ceno odkupil lidijski kralj Kandavlos, imenovan tudi Mirsil, zadnji med Heraklidi. Ta je sicer umrl leta 687 pr. Kr., toda Plinij postavlja njegovo smrt v čas 18. olimpiade (708-705 pr. Kr.) oziroma v leto Romulove smrti 717 pr. Kr. ${ }^{2}$

Po Plinijevem mnenju so slikarstvo odkrili tako, da so z linijo »ob-risali« konturo sence, ki jo je projeciralo človeško telo $(35,15$ : umbra hominis lineis

1 Filosikionska teza, ki jo je Plinij starejši najverjetneje povzel po Ksenokratu iz Aten, je temeljila na zgodovinskem spominu na dva predstavnika sikionske slikarske šole iz arhaične dobe, Telefana $(35,16)$ in Kratona (Atenagora, Legatio, 14). Prvi je veljal za njenega ustanovitelja. Filokorintska teza je bila utemeljena na široko poznanem dejstvu, da je bila v tem mestu slikarska tradicija starodavna, saj je segala v zgodnje arhaično obdobje in je bila dokumentirana s številnimi imeni umetnikov: Kleant, Aridejk, Ekfant $(35,16)$, nadalje Higiajnont, Dejnias, Karmadas $(35,56)$ ter Milonid in Timonid (poznana iz napisov).

2 Pred 90. olimpijado so torej ustvarjali ne le vsi umetniki arhaične dobe, ampak tudi slikarji zgodnjega klasičnega obdobja, med katerimi Plinij omenja Panajnosa, Polignota in Mikona. V času 90. olimpijade (420-417 pr. Kr.) so delovali atenski slikarji Aglaofont, Kefizodor, Erilos in Evenor $(35,60)$. Toda kljub temu da Plinij dokaže častitljivo starost slikarstva, vseeno soglaša $\mathrm{z}$ grškimi viri v tem, da je vrata slikarstvu zares odprl šele Apolodor $(35,61$ : $a b$ hoc artis fores apertas), ki je po avtorjevem pisanju dosegel vrhunec v času 93. olimpijade (408-405 pr. Kr.). 
circumducta). ${ }^{3} \mathrm{~V}$ drugi fazi, ki je imenovana tudi monokromatsko slikarstvo $(35,15$ : secundam singulis coloribus et monochromaton dictam $)$, so figure notranje razdelili s črtami na posamezne ploskve. Nekatere od teh so izpolnili $\mathrm{z}$ eno samo barvo (temno rdečo, dobljeno iz terakote). ${ }^{4}$

Za iznajditelja slikarstva (njegove prve faze) veljata po pisanju Plinija starejšega Filokles iz Egipta ali Kleant iz Korinta $(35,16)$, med prvimi pa sta novo zvrst izvajala Aridejk iz Korinta in Telefan iz Sikiona, ki spadata že $\mathrm{v}$ vmesno fazo, med prvo in drugo $(35,16)$. Tadva sicer še nista uporabljala barve (35, 16: sine ullo etiamnum hi colore), sta pa že razdelila telesa figur na posamezne ploskve (35, 16: spargentes linias intus), obenem sta naslikane like določila $\mathrm{z}$ napisi imen (35, 16: quos pinxere adscribere institutum).

Posamezne ploskve je prvi z barvo izpolnil Ekfant iz Korinta, ki je uporabil temno rdeči pigment, pridobljen iz zdrobljene terakote $(35,16$ : colore testae tritae). Zato velja za iznajditelja druge faze slikarstva. Po Ekfantu so v monokromatski tehniki slikali Higiajnont, Dejnias in Karmadas $(35,56)$, najverjetneje korintski slikarji iz obdobja po letu 670 pr. Kr.

Po sredini 7. stol. pr. Kr. sta se črni barvi kontur in rdeče izpolnjenim ploskvam pridružili še dve drugi barvi, in sicer bela in rumena. S tem se je rodilo tetrakromatsko slikarstvo, ki je tretja faza $v$ razvoju te grške zvrsti $(35,50)$. Kljub nadaljnji bogatitvi barvne lestvice, ki bo veliko prispevala $\mathrm{k}$ živosti grškega slikarstva, pa bo za Plinija starejšega ideal ravno tetrakromatizem, ki ga bo pripisal nekaterim najboljšim slikarjem in zlasti Apelu (35, $50) .^{5}$

Naslednji slikar, ki ga omenja Plinij starejši, je Evmar iz Aten, ki mu pripiše dva dosežka: prvega, da je razlikoval med moškimi in ženskimi liki (35, 56: qui primus in pictura marem a femina discreverit), in drugega, da je

3 Enak postopek zasledimo v anekdoti o sikionskem keramiku Butadesu, ki je deloval v Korintu $(35,151)$. Njegova hčerka je bila namreč zaljubljena v mladeniča, ki je bil prisiljen zapustiti kraj. Da bi ohranila spomin nanj, je zarisala konturo njegove sence, ki je ob svetlobi svetilke padala na steno. Oče je po tem obrisu izdelal terakotni portret mladeniča. Iznajditelja Butadesa datiramo na začetek 7. stol. pr. Kr., ko je bilo slikarstvo že v drugi razvojni fazi. O monokromatskem slikarstvu piše Plinij starejši na več mestih: 35, 15-16, 29 in 56.

5 Plinij starejši, Naravoslovje, 35, 50: quattuor coloribus solis inmortalia illa opera fecere - ex albis Melino, e silaciis Attico, ex rubris Sinopide Pontica, ex nigris atramento - Apelles, Aetion, Melanthius, Nicomachus, clarissimi pictores ... 
posnemal vsakršno figuro $(35,56$ : figuras omnes imitari ausum). Evmar je najverjetneje deloval v letih 580-570 pr. Kr.

Slikarje arhaične dobe sklene Kimon iz Kleon, ki je po Pliniju iznajditelj figur v perspektivični skrajšavi: pisatelj to odkritje poimenuje z grškim izrazom katagrapha in ga prevaja $\mathrm{v}$ latinščino kot imagines obliquae (35, 56); ${ }^{6}$ pozneje se bo v umetnostnozgodovinski literaturi uveljavil izraz scorcio. Kimona omenja tudi pesnik Simonid (Anthologia Planudea, IV, 83-84), ki je slikarja spoznal na Hipijevem dvoru v Atenah (528/527-510 pr. Kr.). Poleg katagrafije je omenjeni atenski slikar vnesel še druge novosti: obraze $\mathrm{v}$ različnih legah, to je obrnjene nazaj, navzgor, navzdol $(35,56$ : et varie formare voltus, respicientes suspicientesve vel despicientes), ude s sklepi in izstopajoče žile $(35,56$ : articulis membra distinxit, venas protulit) ter nagubano draperijo, ki je sledila telesu (35, 56: in vestibus rugas et sinus invenit).

\section{Slikarstvo kot sosledje iznajdb v klasičnem obdobju}

Najstarejši med pomembnimi slikarji klasične dobe je Polignot s Tazosa (470-440 pr. Kr.), ${ }^{7}$ ki je po Plinijevih besedah prvi naslikal ženske v prozornih oblačilih in $\mathrm{z}$ raznobarvnimi pokrivali $(35,58$ : mulieres tralucida veste pinxit, capita earum mitris versicoloribus operuit) ter variiral izraze na obrazih, tako da so odsevali raznolika čustvena stanja (35, 58: os adaperire, dentes ostendere, volutem ab antiquo rigore variare). Polignot in njegov naslednik Mikon iz Aten (470-440 pr. Kr.) sta večinoma uporabljala le štiri osnovne barve, Fidijev brat, slikar Panajnos (450-430 pr. Kr.) pa je barvno lestvico obogatil (35, 57: adeo iam colorum usus increbuerat). Slednji je na prizoru Bitke na Mataronskem polju upodobil zgodovinske osebe z določeno stopnjo fiziognomske podobnosti $(35,57$ : iconicos duces), kar je pomenilo pomemben korak v portretni umetnosti. ${ }^{8}$

6 Plinij starejši, Naravoslovje, 35, 56: hic catagrapha invenit, hoc est obliquas imagines.

7 Datacije umetnikov od Polignota dalje so povzete po: Reinach, A., Textes Grecs et Latins relatifs à l'histoire de la peinture ancienne, Pariz, 1921 (ponovna izdaja Pariz 1985: uvodna študija in komentar Rouveret, A.).

8 Plinij starejši, Naravoslovje, 35, 57: Panaenus quidem frater Phidiae etiam proelium Atheniensium adversus Persas apud Marathona factum pinxit. adeo iam colorum usus increbuerat 
Toda ena najpomembnejših iznajdb klasične dobe je zagotovo linearna perspektiva; za njenega iznajditelja velja Agatarh s Samosa (460-420 pr. Kr.). Plinij starejši ga sicer ne omenja, Vitruvij pa nas v predgovoru v VII. knjigo traktata O arhitekturi (VII, praef., 11) pouči, da je Agatarh pripravil scenografijo (scaenam fecit) za eno od Ajshilovih tragedij. Agatarh je svojo novo iznajdbo natančneje razložil $\mathrm{v}$ posebnem traktatu (de ea commentarium reliquit). ${ }^{9}$ Ker je ta spodbudil dva matematika, Demokrita in Anaksagoro, da sta pisala o perspektivi, ${ }^{10}$ sklepamo, da je Agatarh upodobil "perspektivično veduto". To pomeni, da je na gledališko platno naslikal stavbe in krajino v linearni perspektivi. Vitruvij je Agatarhovo iznajdbo opisal takole: quemadmodum oporteat ad aciem oculorum radiorumque extentionem certo loco centro constituto lineas ratione naturali respondere, uti de incerta re certae imagines aedificiorum in scaenarum picturis redderent speciem et quae in directis planisque frontibus sint figurata, alia abscedentia alia prominentia esse videantur (VII, praef., 11).

Aristotel je v Poetiki, 4, v primerjavi z Vitruvijem, zapisal, da je "scenografijo uvedel Sofokles", vendar ni omenil imena slikarja. ${ }^{11}$ To novost je Aristotel poimenoval z izrazom skenographia, ki pa nima ustreznega latinskega prevoda v antični literaturi. ${ }^{12}$

Agatarh s Samosa bi lahko sodeloval tako z Ajshilom (525-456 pr. Kr.) kot s Sofoklom (496-406/405 pr. Kr.), kajti ko je bila leta 458 pr. Kr. upodobljena Ajshilova Oresteja, je bil Sofokles že celo desetletje navzoč na odrskih deskah. Toda samoški slikar je scenografijo v obliki perspektivične vedute najverjetneje naslikal za Ajshilovo Orestejo, kajti gre za prvo grško dramsko trilogijo, ki predvideva ozadje v podobi stavbe (na primer palačo Atridov v

adeoque ars perfecta erat, $u$ in eo proelio iconicos duces pinxisse tradatur, Atheniensium Miltiadem, Callimachum, Cynaegirum, barbarorum Datim, Artaphernen.

9 Vitruvij, VII, praef., 11: namque primum Agatharchus Athenis Aeschylo docente tragoediam scaenam fecit et de ea commentarium reliquit.

10 Vitruvij, VII, praef., 11: ex eo moniti Democritus et Anaxagoras de eadem re scripserunt.

11 Aristotel, Poetika, 4: tris kai skenographia Sophocles.

12 Dobesedni pomen izraza skenographia je "poslikava skene", to je platna (prvi pomen skene je namreč platno). Torej gre za "poslikavo platen velikih dimenzij", ki so bila napeta v lesenem okvirju oziroma na leseni podporni strukturi. 
Argosu ali Apolonov tempelj v Delfih). Sofokles pa je verjetno Agatarhovo novost sistematično uporabljal.

E. Panofsky je opozoril na razliko med renesančno in antično perspektivo, ki jo je označil z izrazom “osna perspektiva”. Pri drugi namreč ni enotnega fokusa, kamor bi se stekale vse daljice, ampak so očišča razporejena po osrednji osi (Panofsky, 1927).

Nadalinja stopnja v razvoju proti naturalizmu je upodabljanje »svetlobe in senc z uporabo med seboj nasprotujočih si barv« (35, 29: lumen atque umbras, differentia colorum alterna vice sese excitante). Grški strokovni izraz za to odkritje je skiagraphia, ${ }^{13}$ kar Plinij starejši latini kot lumen et umbrae.

Čeprav številni viri soglašajo, da je novost uvedel Apolodor iz Aten (430-400 pr. Kr.) okoli leta 450 pr. Kr., ${ }^{14}$ Plinij starejši tega dosežka ne pripisuje kakemu določenemu slikarju. $V$ antični literaturi pa zasledimo tudi alternativno ime iznajditelja, saj Cicero (Brut, 70) pa tudi Kvitilijan (Izobraževanje govornika, XII, 10,4) menita, da ima pri tem največ zaslug Zevksis iz Herakleje (425-397 pr. Kr.).

V strokovni literaturi so bile zapisane različne intepretacije skiagrafije, ki jih lahko strnemo v dve osnovni. G. Richter razume skiagrafijo kot senčenje, to je razlikovanje med osvetljenimi in osenčenimi deli teles, kar poudari prostorsko-plastični učinek (Richter, 1970). E. Keuls vzame Plinijev citat dobesedno in prepozna $\mathrm{v}$ njem principe poznejše divizionistične tehnike, ki izrablja optično fuzijo barv. Apolodor je domnevno tako nanesel drugo ob drugi lise kontrastnih barv, ki pravilno učinkujejo šele ob pogledu na daleč (Keuls, 1978).

Čeprav imamo iz rimskega obdobja stenske poslikave, ki dokazujejo obe razlagi, pa je bolj verjetno, da je šlo pri Apolodorju (oziroma Zevksisu) za uporabo senčenja. Divizionistična tehnika je značilna za tako imenovano picturo compendiario, ki je mlajša po nastanku, saj se je, sicer na helenističnih temeljih, uveljavila v Rimu konec 1. stol. po Kr. Toda antična tehnika senčenja se razlikuje od renesančne, saj svetloba ne izhaja iz enotnega vira,

13 Hezihij, v: Reinach, 1985, str. 186, kat. 195.

14 Na primer Plutarh, De gloria Atheniensium, 2; Hezihij, v: Reinach, 1985, str. 186, kat. 195. 
temveč so osvetljeni in osenčeni deli postavljeni tako rekoč funkcionalno, da čim bolj poudarijo plastičnost teles.

Tudi Parazij iz Efeza (420-370 pr. Kr.) je v uvedel veliko novosti (35, 67: et ipse multa contulit). Popolnoma je v slikarstvu uveljavil simetrijo (35, 67: primus symmetrian picturae dedit), obenem je kot prvi naslikal obraz $\mathrm{v}$ vseh njihovih podrobnostih ter elegantnost frizure in ljubkost ustnic (35, 67: primus argutias voltus, elegantiam capilli, venustatem oris).

Toda $\mathrm{v}$ razvoju slikarstva je pomemben zato, ker je iznašel tako imenovano funkcionalno linijo, ki je v neprekinjenem teku "ob-risala" telo ter $\mathrm{s}$ konturo določila njegovo plastičnost in postavitev v prostor. Slikarjevo iznajdbo je Plinij starejši osvetlil s temi besedami: corpora enim pingere et media rerum est quidem magni operis, sed in quo multi gloriam tulerint; extrema corporum facere et desinentis picturae modum includere rarum in successu artis invenitur. ambire enim se ipsa debet extremitas et sic desinere, ut promittat alia et post se ostendatque etiam quae occultat $(35,67-68)$.

Parazijeva funkcionalna linija je delovala kot kontura v reliefnem kiparstvu, saj je brez senčenja, le z ustreznim obrisom, ustvarila vtis prostorske postavitve.

$\mathrm{Na}$ tej točki zgodovinskega razvoja se je prvič ustvaril kontrast med barvnim in linearnim slikarstvom, ki je poosebljen v nasprotju med Apolodorom in Zevksisom na eni strani ter Parazijem na drugi, nasprotjem, ki se bo v 4. stol. pr. Kr. ponovilo, le da $\mathrm{z}$ drugima protagonistoma, to je $\mathrm{z}$ Apelom proti Protogenu. Glavna razlika med obema tendencama je ta, da so pri barvnem slikarstvu liki postavljeni v prostor in plastično oblikovani s senčenjem (chiaroscuro), pri linearnem slikarstvu pa so podobni učinki doseženi s funkcionalno linijo, ki s konturo (disegno) zariše volumen figur.

Pri »barvnem slikarstvu« je, po mnenju Plinija starejšega, lumen et umbrae nadgradil splendor, alius hic quam lumen $(35,29)$. Splendor bi morda lahko prevajali kot odblesk ali sijaj. V primerjavi z osvetljenostjo je ta tehnični dosežek posnemal močan odsev »žive« luči. Plinij starejši odkritja sicer ne datira, vendar se to sklada s prizadevanji poznoklasičnega slikarstva 4. stol. pr. Kr., tako sikionske kot tebansko-atiške šole.

Razvoj »barvnega pola« grškega slikarstva najlepše povzemajo naslednje Plinijeve besede: Quibus coloribus singulis primi pinxissent diximus, 
cum de iis pigmentis traderemus in metallis, quae monochromata a genere picturae vocantur. qui deinde et quae invenerint et quibus temporibus, dicemus in mentione artificum, quoniam indicare naturas colorum prior causa operis instituti est. tandem se ars ipsa distinxit et invenit lumen atque umbras, differentia colorum alterna vice sese excitante. postea deinde adiectus est splendor, alius hic quam lumen. quod inter haec et umbras esset, appellarunt tonon, commissuras vero colorem et transitus harmogen $(35,29)$.

Avtor sklene 29. poglavje $\mathrm{z}$ razlago dveh strokovnih izrazov: tonos in harmoge. Prvi označuje postopen prehod med osvetljenimi in osenčenimi deli, drugi sfumirano "prelivanje« med različnimi barvami.

Kot zadnjega med umetniki, ki so pomembno prispevali k razvoju slikarske tehnike, Plinij omenja Aristejda II. iz Teb (360-310 pr. Kr.), predstavnika tebanske šole iz 4 . stol. pr. Kr. Ta je kot prvi naslikal izrazita čustvena stanja, ki jih Plinij poimenuje ethe, item perturbationes $(35,98) .{ }^{15}$ Toda ker je bilo slikanje etosa $\mathrm{z}$ vidika etične drže protagonistov pripisano že Polignotu (Aristotel, Poetika, 6), je bolje, da teh dveh izrazov ne mešamo. Med izrazoma ethe in pathos so razlikovali tudi rimski avtorji. Cicero (Tuskulanski razgovori, III, 4, 7) je ethe prevajal z mores, pathos s perturbationes, Kvintilijan (Izobraževanju govornika, VI, 2, 8-28) ethe ravno tako $\mathrm{z}$ mores, medtem ko je pathos latinil kot adfectum. Etos torej lahko interpretiramo kot značaj, patos pa kot intenzivna čustva, afekte. Oboje je bilo značilno za sočasno grško gledališče, patos pa zlasti za govorništvo, saj je spodbudil emotivno uživetje naslovnika.

Plinij starejši omenja tudi druge, manjše novosti, kajti v svojem delu sledi konceptu Ksenokrata iz Aten, po katerem je razvoj likovnih umetnosti kot sosledje iznajdb na poti k naturalizmu. Vsak pomemben umetnik je - bodisi kot "iznajditelj" ali "dovršitelj" - bistveno prispeval k evoluciji slikarske tehnike. Toda vse iznajdbe niso enako pomembne in po mnenju E. Keuls so štirje temeljni pojmi grškega slikarstva naslednji: katagrafija ali perspektivična skrajšava, skenografia ali linearna perspektiva, skiagrafija ali senčenje in upodabljanje dramatičnih čustvenih izrazov na obrazih do patetičnosti.

15 Plinij starejši, Naravoslovje, 35, 98: is omnium primus animum pinxit et sensus hominis expressit, quae vocant Graeci $\eta \theta \eta$, item perturbationes. 


\section{Slikarske šole 4. stoletja pr. Kr.}

$\mathrm{Za}$ ustanovitelja starejše ali sikionske šole velja Evpomp iz Sikiona, ki je deloval okoli leta 400 pr. Kr. Plinij starejši pravi, da je Evpomp v grško slikarstvo, ki se je dotlej delilo na helensko in aziatsko, uveljavil še tretjo, sikionsko smer. Tako so bile potlej v slikarstvu tri šole: jonska, ki je sinonim za aziatsko, ter sikionska in atiška $(35,75) .{ }^{16}$

Evpompov učenec Pamfil iz Amfipolisa (400-350 pr. Kr.), ki je bil zelo izobražen, zlasti $\mathrm{v}$ aritmetiki in geometriji, je povzdignil poučevanje tabelnega slikarstva na akademsko raven. Njemu je treba pripisati zaslugo, da je slikarstvo stopilo v grško pajdejo - sprva v Sikionu, potem po vsej Grčiji - in postalo enakopravno matematiki, poeziji in glasbi, ki so doslej bile temelj grškega izobraževanja $(35,77) .{ }^{17}$ Pamfil je teorijo in veščine tabelnega slikarstva poučeval po zgledu sofistov za plačilo, in to za visoko ceno enega talenta na leto $(35,76)$. Iz Pamfilove šole so izšli trije pomembni slikarji: Pavzija (380-330 pr. Kr.) in Melantij (370-330 pr. Kr.), oba iz Sikiona, ter najslavnejši med sikionskimi slušatelji, Apel iz Kolofona pri Efezu (360-300 pr. Kr.).

Mlajšo ali tebansko-atiško šolo je ustanovil Aristejd I. iz Teb, ki je obvladal bodisi kiparstvo v bronu (Plinij ga postavlja med Poliklejtove učence)

16 Plinij starejši, Naravoslovje, 35, 75: ipsius auctoritas tanta fuit, ut diviserit picturam: genera, quae ante eum duo fuere - Helladicum et Asiaticum appellabant -, propter hunc, qui erat Sicyonius, diviso Helladico tria facta sunt, Ionicum, Sicyonium, Atticum.

Genus Asiaticum, pozneje imenovan genus Ionicum, vključuje slikarje iz geografskega območja maloazijske obale in pripadajočih otokov: Evenorja in Parazija iz Efeza, Agatarha s Samosa, Kolota s Teosa (Cicero, Orationes, XXII, 74), Androkida iz Cizika (Plinij starejši, Naravoslovje, 35, 64) itd. Tej smeri lahko pripišemo naslednje značilnosti: znanstveno utemeljenost umetnosti (Agatarh je iznašel perspektivo, Parazij funkcionalno linijo; Androkid je bil izrazit naturalist), hedonistične in pogosto frivolne vsebine, ki so odsevale pregovorno ležerno jonsko življenje (Parazijeve erotične sličice; Androkid je slikal ribe, ki jih je nadvse rad jedel), in nežne barvne tone (Parazijev Tezej je naslikan tako, "kot bi se hranil z vrtnicami” - Plinij starejši, Naravoslovje, 35, 129).

Genus Helladicum pomeni predvsem atiško slikarstvo in obsega slikarje različnih provenienc, ki so se preselili v Atene, saj so bile v 5. stol. pr. Kr. vodilni center grškega slikarstva. Med številnimi velja omeniti Polignota, Mikona, Panajnosa, Apolodora, Zevksisa in Timanta. Z ustanovitvijo sikionske smeri (genus Sicyonium) se pomen Aten zmanjša (kar sovpade $\mathrm{s}$ koncem atenske hegemonije po peloponeških vojnah) in heladsko slikarstvo s centrom v Atenah se preimenuje v atiško (genus Atticum).

17 Slikarstvo je bilo sprejeto v prvo stopnjo svobodnih umetnosti: recipereturque ars ea in primum gradum liberalium $(35,77)$. 
bodisi slikarstvo. ${ }^{18}$ Imel je številne učence, šola pa se je pozneje razdelila v dve smeri: tebansko in atiško.

Med tebanskimi mojstri je treba najprej omeniti Nikomaha iz Teb (390340 pr. Kr.), ki je sprva deloval v Atenah, ${ }^{19}$ po letu 334 pr. Kr. pa se je preselil v Makedonijo, kjer je v času Aleksandrovih pohodov na vzhod vladal Antipater (334-323 pr. Kr.). Plinij starejši je Nikomahu med številnimi deli kot najpomembnejše pripisal sliko Ugrabitve Perzefone, ki je bila razstavljena $\mathrm{v}$ Templju kapitolinske triade $\mathrm{v}$ Rimu $(35,108) .{ }^{20} \mathrm{Na}$ podlagi tega zapisa, dveh rimskih replik znamenite slike ( $\mathrm{v}$ tehniki mozaika $\mathrm{z}$ nagrobno funkcijo) in biografskega podatka, da se je Nikomah po letu 334 pr. Kr. preselil v Makedonijo, velja v strokovnih krogih prepričanje, da je ravno Nikomah (ali njegova delavnica) avtor poslikave tako imenovane Perzefonine grobnice v makedonski Vergini (slik. 1). Nikomah je tako prvi grški slikar, ki mu lahko pripišemo original.

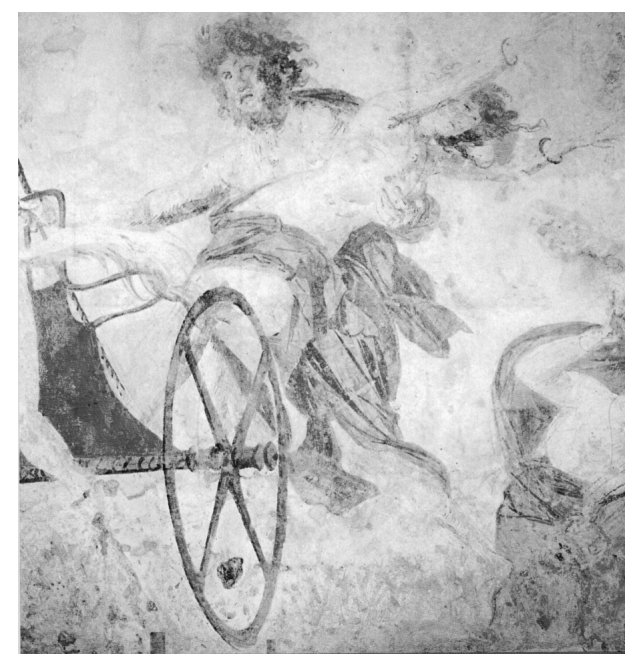

slik. 1: Poslikava Perzefonine grobnice v Vergini, ok. 330 pr. Kr. vir: Moreno (1987)

18 Plinij starejši, Naravoslovje, 34, 50 in 72 (za kiparstvo v bronu); 35, 75 (za slikarstvo).

19 Slikar Nikomah morda sovpada s kiparjem v bronu, ki je deloval v Atenah in je omenjen v treh napisih, ki pripadajo kipom $\mathrm{z}$ območja akropole.

20 Plinij starejši, Naravoslovje, 35, 108: pinxit raptum Proserpinae, quae tabula fuit in Capitolio in Minervae delubro supra aediculam Iuventatis. 
Med učenci Nikomaha iz Teb $(35,110)$ sta bila najznamenitejša že omenjeni Aristejd II. iz Teb (360-310 pr. Kr.), ki mu Plinij starejši pripisuje novost slikanja etosa in patosa $(35,98)$, in Filoksen iz Eretrije (350-300 pr. Kr.), o katerem rimski polihistor zapiše, da je za makedonskega kralja Kasandra naslikal Aleksandrovo bitko $z$ Darejem $(35,110) .{ }^{21} \mathrm{Na}$ podlagi tega zapisa in po primerjavi z Nikomahovo poslikavo Perzefonine grobnice $\mathrm{v}$ Vergini so strokovnjaki Filoksenu pripisali slikarski original, katerega kopija je znameniti mozaik z Aleksandrovo bitko iz Favnove hiše v Pompejih (hranjen v neapeljskem Nacionalnem arheološkem muzeju; slik. 2).

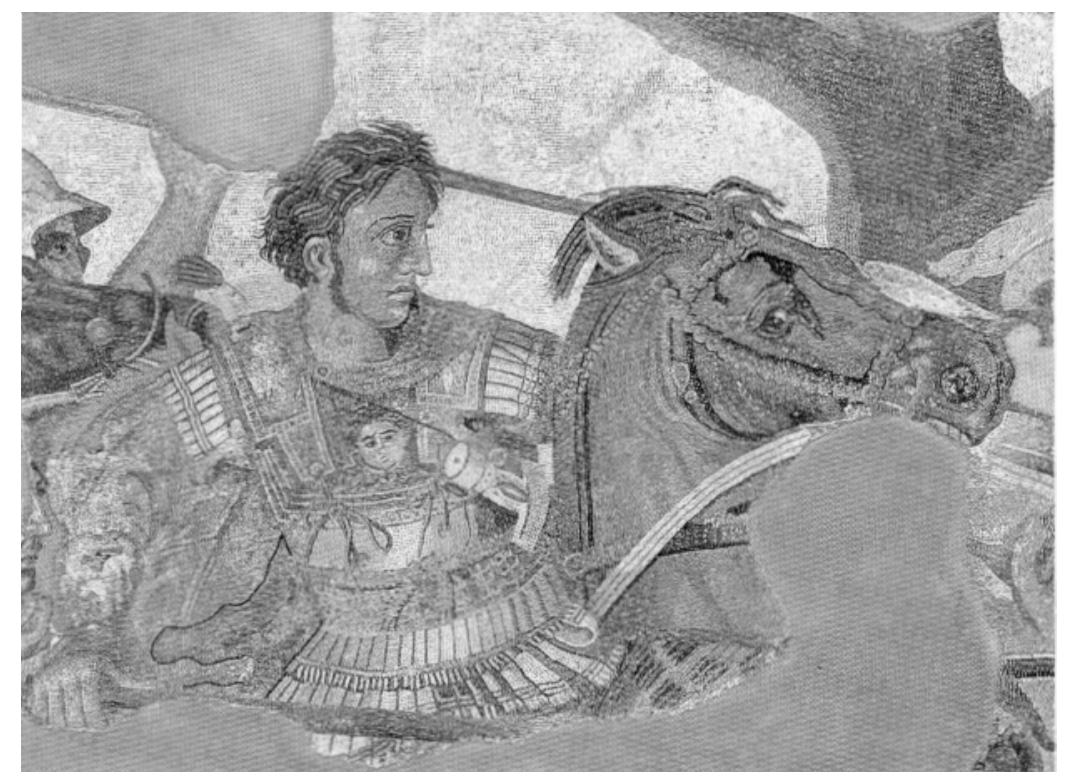

slik. 2: Spopad med Aleksandrom in Darejem, mozaik iz Favnove hiše v Pompejih, sredina 2. stol. pr. Kr. (Neapelj, Nacionalni arheološki muzej). vir: Moreno (1987)

Med slikarji atiške šole izstopata zlasti Evfranor iz Korinta (400-330 pr. Kr.) in Nikias iz Aten (350-300 pr. Kr.), ki sta bila specialista v tehniki enkavstike. Iz zapisa Plinija starejšega izvemo, da je bil Nikias vešč slikar

21 Plinij starejši, Naravoslovje, 35, 110: cuius tabula nullis postferenda, Cassandro regi picta, continuit Alexandri proelium cum Dario. 
živali, zlasti konj in psov $(35,133$ : quadripedum prosperrime canes expressit). Na podlagi teh opažanj in po primerjavi z drugimi Nikiasovimi deli (po rimskih kopijah, zlasti zidne slike Argosa, Io in Hermesa v Livijini hiši na Palatinu) večina arheologov soglaša, da je Nikias avtor poslikave tako imenovane Grobnice Filipa II. v makedonski Vergini (slik. 3).

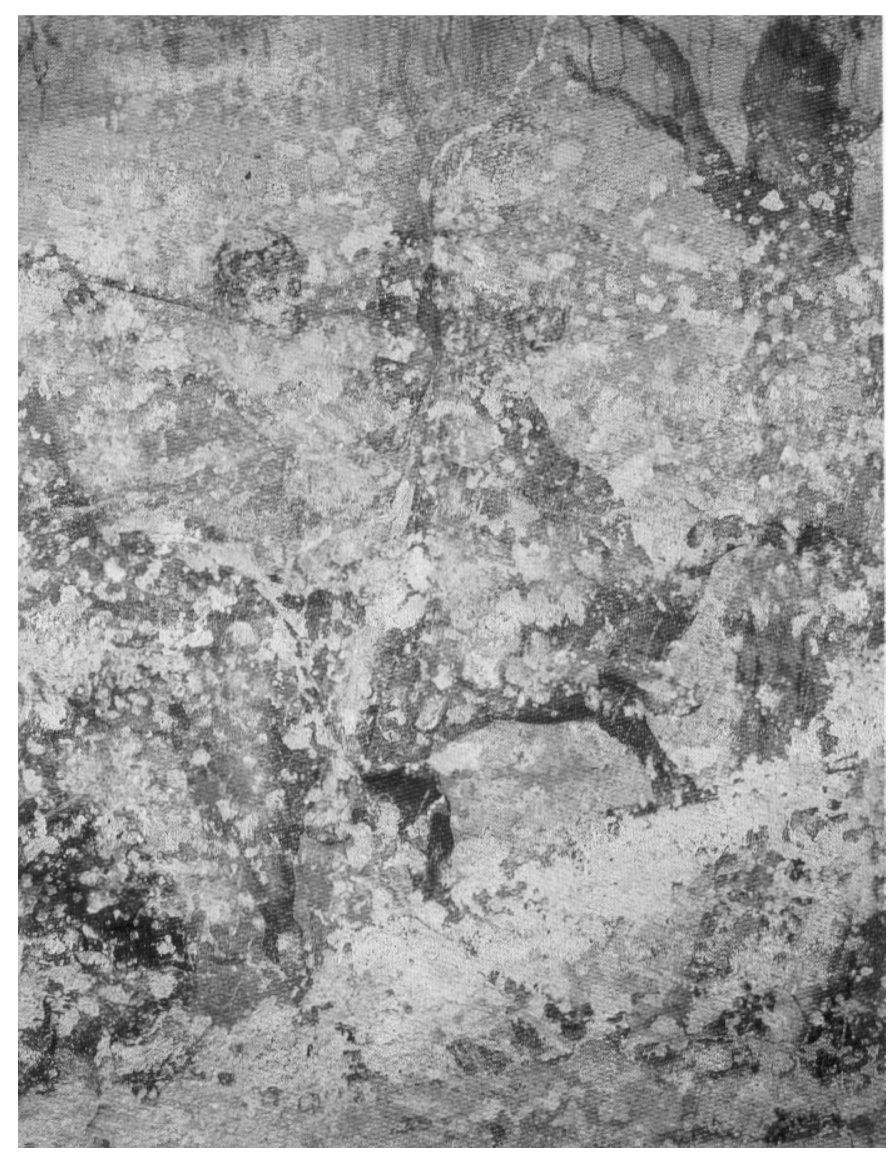

slik. 3: Poslikava grobnice Filipa II. Makedonskega v Vergini, ok. 330 pr. Kr. vir: Moreno (1987)

Nikias se je v zgodovino grške umetnosti zapisal tudi zato, ker je poslikal Praksitelove marmorne kipe $(35,133) .{ }^{22}$ Gre za circumlitio, poslikavo po-

22 Plinij starejši, Naravoslovje, 35, 133: hic est Nicias, de quo dicebat Praxiteles interrogatus, 
sameznih partij, kot so lasje, draperija, itd. Ostanke pigmentov so našli na Praksitelovem Hermesu (vendar je tu še vedno vprašanje datacije kipa, ki ga večina avtorjev postavlja $\mathrm{v}$ helenistično obdobje) in na Aleksandrovem sarkofagu, ki je pripisan enemu od Praksitelovih sinov.

Med predstavniki jonske šole Plinij starejši omenja le Ajtiona (330-280 pr. Kr.), ki je dosegel slavo s prizorom Poroke med Aleksandrom in Roksano $(35,78) .{ }^{23}$ Delo je razstavil v Olimpiji in si tako zaslužil nepričakovano nagrado: sodnik Proksenid mu je dal v zakon svojo hčerko.

\section{Apel iz Kolofona pri Efezu (360-300 pr. Kr.) kot najpomembnejši grški slikar}

Apel, najslavnejši slikar antične dobe, se je rodil v Efezu in ne na otoku Kosu, kot je zapisal Plinij starejši $(35,79) .{ }^{24} \mathrm{~S}$ slikarsko veščino se je najprej spoznal pri Eforu iz Efeza, potem pa se je zaradi njenega slovesa priključil sikionski šoli, v kateri se kot Apelov učitelj navaja Pamfil iz Amfipolisa. ${ }^{25}$ Iz Apelovega bivanja na grškem polotoku se v virih omenja še srečanje $s$ prelepo hetero Laido, ki je živela v Korintu (Atenaj, XIII, 588 c).

Odločilnega pomena na umetnikovi ustvarjalni poti je bilo srečanje $\mathrm{z}$ Aleksandrom Velikim v Efezu leta 334 pr. Kr. Makedonski vojskovodja je slikarja izjemno cenil in z njim se je ujel tudi po človeški plati. Aleksander je velikokrat obiskal Apelovo slikarsko delavnico in o tem se je ohranila zanimiva anekdota. ${ }^{26}$ Med enim od obiskov se je namreč znameniti vojsko-

quae maxime opera sua probaret in marmoribus: quibus Nicias manum admovisset; tantum circumlitioni eius tribuebat.

23 Plinij starejši, Naravoslovje, 35, 78: nova nupta verecundia notabilis. Slika je znana po Lukijanovem opisu (Herodot ali Ajtion, 4-6; Podobe, 7).

24 Poleg Plinija starejšega je Kos kot rojstni otok Apela omenil tudi Ovidij (Ars amatoria, III, 401): na otoku Kosu je Apel verjetno dobil državljanstvo, potem ko se je po Aleksandrovem pogrebu leta 322 pr. Kr. preselil tjakaj. Številni drugi viri soglašajo, da se je Apel rodil v Efezu, med drugimi tudi Strabo (XIV, 1, 25).

25 Slikar Efor iz Efeza je omenjen le v enem viru (Suda, a 3008); Plinij starejši postavlja za Apelovega učitelja Pamfila iz Amfipolisa $(35,75)$.

26 Plinij starejši je ohranil precej anekdot iz Apelovega življenja in delovanja. To lahko pripišemo bodisi dejstvu, da je bil Apel znamenit slikar in je njegovo življenje ponujalo zanimive prigode, bodisi ker je Plinij številne podatke povzel po Durisu s Samosa, ki je svoj umetno- 
vodja spozabil in na dolgo razpredal o slikarstvu, ne da bi se spoznal na sam predmet. Apel ga je vljudno povabil, naj molči, kajti smejali so se mu celo slikarski pomočniki, ki so pripravljali barve $(35,85-86)$.

Aleksander je slikarju naročil, naj zaradi izjemne lepote naslika golo Pankaspo iz Larise, ki je bila med vsemi konkubinami Aleksandru najljubša. Umetnik se je, ganjen od tolikšne lepote, zaljubil v svoj model. Ko je Aleksander opazil Apelova čustva, se ni razjezil, ampak se je svoji ljubezni odpovedal in deklico poklonil slikarju $(35,86-87)$.

Plinij starejši je zapisal, da je "brezpredmetno šteti, kolikokrat je Apel naslikal Aleksandra in Filipa” $(35,93) .{ }^{27}$ Veliko število Apelovih upodobitev mladega makedonskega voskovodje je že v antiki ustvarilo legendo, da se je ta pustil upodabljali samo Apelu med slikarji, Lizipu med kiparskimi mojstri in Pirgotelu med gliptiki. ${ }^{28}$ Aleksander je namreč zelo skrbel za ustrezno propagiranje svoje podobe in ni hotel, da bi jo roka kakega drugorazrednega umetnika "spridila" in bi se potem med ljudstvom širile "nedostojne" kopije.

Vsa ta pričevanja kažejo na spremembo v statusu umetnika ob koncu 4. stol. pr. Kr.: Apela najprej srečamo kot predstavnika neke mestne šole, kmalu zatem pa postane, skupaj s kiparjem Lizipom, vodilni dvorni umetnik novega gospodarja sveta, Aleksandra Velikega. Lizip in Apel sta tako postavila pravila grške avlične umetnosti s posebnim poudarkom na kraljevski ikonografiji in vladarjevi podobi.

Po smrti Aleksandra Velikega si je Apel za svoj novi dom izbral otok Kos, za kratek čas pa se je leta 305 ali 304 pr. Kr. mudil sprva v Aleksandriji, potem na otoku Rodosu. ${ }^{29}$

stnozgodovinski traktat zasnoval biografsko.

27 Plinij starejši, Naravoslovje, 35, 93: Alexandrum et Philippum quotiens pinxerit, enumerare supervacuum est.

28 Plinij starejši, Naravoslovje, 7, 125: idem hic imperator edixit ne quis ipsum alius quam Apelles pingeret, quam Pyrgoteles scalperet, quam Lysippus ex aere duceret; o Apelu izrecno tudi v 35 , 85.

29 Datacija je podkrepljena z dejstvoma, da se Ptolemaj I. v Aleksandriji oklical za kralja leta 305 pr. Kr., Apel pa si je na Rodosu ogledal sliko Jaliza, ki jo je Protogen dokončal leta 305-304 pr. Kr. 
Po pisanju Plinija starejšega je Apela v Aleksandrijo zaneslo po naključju, zaradi nevihte, kajti med vsemi Aleksandrovimi nasledniki je bil ravno Ptolemaj I. tisti, s katerim nista bila v najboljših odnosih $(35,89)$. Ob tej priliki so Apelovi rivali podplačali dvornega norčka, da je slikarja v kraljevem imenu povabil na dvor. Ko se je le-ta zglasil pri Ptolemaju I. na kosilu, se je kralj namrdnil in mu naročil, naj med služabniki pokaže na tistega, ki ga je povabil na lastno pest. Apel je poprijel za kos oglja in na steno skiciral podobo nesrečnika. Tako se je porodila karikatura $(35,89)$.

Iz časa Apelovega postanka v Egiptu je znana še ena anekdota, ki pravi, da je Apelov izjemni talent sprožil zavist pri rivalu, slikarju Antifilu iz Egipta (310-280 pr. Kr.). Ta je tekmeca pri kralju po krivem obdolžil sodelovanja pri zaroti, ki jo je v Tiru pripravil Teodot. Ptolemaj je obrekovanju nasedel in je, ne da bi karkoli preveril, začel divje besneti nad Apelovo "izdajo". Šel bi še dlje, če ga ne bi ustavil eden od zarotnikov in mu odprl oči za Antifilovo prevaro. Ptolemaju je bilo zaradi neprijetnega dogodka tako žal, da je dal Apelu sto talentov, Atifilu pa je vzel svobodo. Apel je pozneje svojo neprijetno izkušnjo ilustriral $\mathrm{z}$ alegorično sliko z naslovom Obrekovanje.

Po postanku v Aleksandriji se je Apel za kratek čas ustavil na Rodosu (35, 81-83), kjer je obiskal svojega sodobnika, slikarja Protogena iz Kavnosa v Kariji (330-290 pr. Kr.). Tu se je, brž ko se je izkrcal, odpravil proti umetnikovem ateljeju, da bi z lastnimi očmi "videl dela slikarja, ki ga je poznal le po slavi” $(35,81)$. Ker ga ni našel v ateljeju, je na sliki, ki jo je imel Protogen ravno v delu, potegnil izjemno tanko linijo. Ko se je Protogen vrnil, je takoj spoznal, koga ima v gosteh, in sredi Apelove linije je narisal še tanjšo. Apel je seveda ponovil obisk: na sliki je sredi Protogenove linije zarisal tako tanko črto, da jo je bilo nemogoče prepoloviti. Ko je Protogen to videl, je takoj stekel v pristanišče h kolegu in mu pripoznal zmago. Sliko je pozneje pustil nedokončano, da se je ohranila kot dokaz slikarskega tekmovanja med znamenitima sodobnikoma. Plinij si je sliko ogledal v cesarski palači na Palatinu $(35,83)$, kjer pa je zgorela v požaru leta 64 po Kr.

Plinij starejši nam je ohranil tudi nekaj anekdot iz Apelovega ateljeja, ki lepo ilustrirajo umetnikov način dela. Apel je imel ustaljeno navado, da je vsak dan, čeprav je bil še tako zaposlen z drugimi opravki, zarisal vsaj eno linijo. Iz tega se je oblikoval pregovor: "nulla dies sine linea" $(35,84)$. 
Potem ko je neko sliko dokončal, jo je razstavil v portiku, tako da so si jo lahko mimoidoči dobro ogledali in morda opazili kako napako. Apel, ki se je skril za sliko, je pozorno poslušal kritike ljudstva in je pozneje pomanjkljivosti popravil. Tako ga je neki mimoidoči čevljar opozoril, da se je zmotil pri slikanju čevlja. Toda ko je imel naslednji dan ta isti čevljar pripombe še na noge, se je Apel razjezil in mu zabrusil: "ne supra crepidam sutor" (35, 84-85), kar je tudi prišlo v pregovor.

Razen omenjenih dveh potovanj v Aleksandrijo in na Rodos se Apel ni premaknil z otoka Kosa. Najverjetneje je tu tudi umrl, in sicer, kot pravi Plinij, med slikanjem svoje zadnje in morda tudi največje umetnine, nedokončane slike boginje Afrodite $(35,92)$.

Plinij starejši je ohranil številne naslove Apelovih del, saj so mnoga med njimi veljala za mojstrovine grške umetnosti. Na prvem mestu moramo predstaviti Apelove portrete Aleksandra Velikega, s katerimi je slikar prispeval odločilen delež k oblikovanju sprva helenistične in pozneje rimske podobe vladarja.

Antični viri izrecno omenjajo štiri Apelove podobe makedonskega vojskovodje: Aleksandra Keraunofora ("Aleksandra, ki nosi strelo"; 35, 92) in Aleksandra na konju (Elijan, Varia Historia, II, 3), obe za Artemidin tempelj v Efezu, ter dvojico slik z motivom zmagoslavnega Aleksandra, katerih izvorno nahajališče ni znano, pozneje pa sta našli prostor na Avgustovem forumu v Rimu (35, 27 in 93-94).

Aleksander Keraunofor pomeni veliko inovacijo v ikonografiji vladarja, saj je upodobljen $\mathrm{z}$ božanskimi atributi in tako asimiliran $\mathrm{z}$ izbranim bogom. V strokovni literaturi je tovrstna ikonografija poimenovana kot transfigurirana ali preoblikovana podoba vladarja. ${ }^{30} \mathrm{Na}$ Apelovi sliki gre za Aleksandra v podobi Zevsa Amona. Iz številnih Aleksandrovih biografij namreč izvemo, da se je po obisku egipčanske oaze Siwah, kjer je stal tempelj omenjenega boga, makedonski vojskovodja proglašal za Zevsovega sina. Apelova podoba je tako med grškimi romarji, ki so množično obiskovali efeško svetišče, razširjala Aleksandrovo vladarsko ideologijo.

$30 \mathrm{~V}$ primerjavi z Lizipovo kiparsko podobo Aleksandra Velikega, ki je postavila inspirirano ali navdihnjeno podobo vladarja. Lizip je kralja upodobil v herojski goloti, z značilnim obratom glave, dvignjenim kodrom las in v nebo povzdignjenim pogledom. 
V Plinijevem opisu so nakazane tudi slikarske kvalitete znamenitega dela. Čeprav pripada Apel tistim grškim slikarjem, ki so uporabljali le štiri barve $(35,50)$, je bilo delo narejeno s takim realizmom, da se je zdelo, kot da bi prsti in strela iztopali iz slikarske površine $(35,92) .{ }^{31}$ Obenem pa naj bi Apel Aleksandra upodobil nekoliko bolj zagorelega, kajti v resnici je bila njegova koža rožnato bela (Plutarh, Aleksander, 4).

Slika je nastala v času Aleksandrovega postanka v Efezu leta 334 pr. Kr. Njen približen videz nam ilustrira zidna poslikava $\mathrm{z}$ isto vsebino iz Hiše Vetijcev v Pompejih (slik. 4).

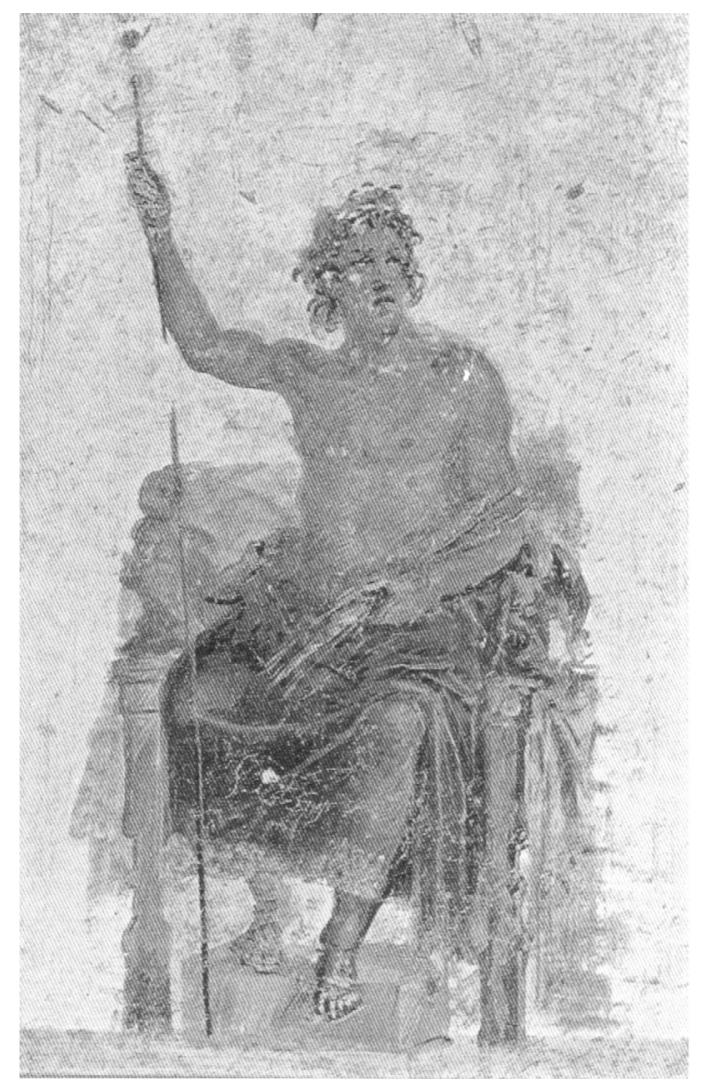

slik. 4: Aleksander Keraunofor, Hiša Vetijcev v Pompejih, po 62 po Kr. vir: Moreno (1987)

31 Plinij starejši, Naravoslovje, 35, 92: digiti eminere videntur et fulmen extra tabulam esselegentes meminerint omnia ea quattuor coloribus facta-. 
Plinij starejši nas pouči, da je Avgust na eminentnem mestu svojega foruma razstavil dvojico sliko z zmagoslavno podobo Aleksandra Velikega: na desni Aleksandra med Dioskuroma in Nike, na levi Aleksandra na triumfalnem vozu ob premagani Vojni $\left(35,27\right.$ in 93). ${ }^{32}$ Slednja naj bi izhajala iz pogrebnega voza makedonskega vojskovodje - ta je bil okrašen s štirimi tabelnimi slikami, ki so bile delo Apela in njegovih učencev -, čeprav ne ustreza povsem opisu Diodora Sikulskega. Iz Diodorovega pričevanja (XVIII, 26-27) namreč izvemo za štiri upodobljene motive. Kot prvega omenja Aleksandra na vozu z žezlom $v$ roki (ob njem osebno spremstvo s kraljevim orožjem, zadaj osebna straža Makedoncev in Perzijcev); to sliko je domnevno Avgust razstavil na svojem forumu. Sledile so Četa slonov v popolni bojni opravi (spredaj na slonih Indijci, zadaj Makedonci, oboji s tipičnim nacionalnim orožjem), Sprevod konjenice v vojni opravi in Vrsta bojnih ladij.

$\mathrm{V}$ ta okvir spadata tudi dve Apelovi sliki Aleksandrovih tovarišev Klitosa in Neoptolema, ki se na konjih v diru spuščata v bitko s Perzijci $(35,93$ in 96).$^{33}$ Najverjetneje sta oba upodobljena pred bitko pri Graniku leta 334 pr. Kr., v kateri je Klitos rešil Aleksandru življenje, naslikana pa sta bila še istega leta $\mathrm{v}$ Efezu. Motiv lahko prištejemo med upodobitve bitk, ki so bile značilne za atensko slikarstvo 5. stol. pr. Kr. in za slikarske šole 4. stol. pr. Kr., pri Lizipu pa najdemo vzporednice $\mathrm{z}$ bronasto kiparsko skupino Aleksandrove bitke pri Graniku, ki je bila postavljena v makedonskem Dionu.

Dejstvo, da je bil Apel dvorni portretist Aleksandra Velikega, mu je prineslo veliko naročil za portretiranje znamenitih oseb svojega časa, med katerimi je treba omeniti zlasti kralja Antigona I., ki je bil od svojega izkrcanja

32 Plinij starejši, Naravoslovje, 35, 27: super omnes divus Augustus in foro suo celeberrima in parte posuit tabulas duas, quae Belli faciem pictam habent et Triumphum, item Castores ac Victoriam; in 35, 93: Romae Castorem et Pollucem cum Victoria et Alexandro Magno, item Belli imaginem restrictis ad terga manibus, Alexandro in curru triumphante.

Servij (Scholia in Vergilium Aeneis, I, 294) omenja, da je bil na podobi Aleksandra na triumfalnem vozu ob premagani Vojni poleg Bellum upodobljen tudi Furor.

Sliki sta bili najverjetneje vzidani v stene avle, ki je zaključevala zahodni portik Avgustovega foruma (ohranili so se okvirji). Cesar Klavdij je na slikah Aleksandrov obraz zamenjal z Avgustovim; o tem Plinij starejši, Naravoslovje, 35, 94: quas utrasque tabulas divus Augustus in celeberrimis partibus dicaverat simplicitate moderata; divus Claudius pluris existimavit utrisque excisa Alexandri facie divi Augusti imagines addere.

33 Plinij starejši, Naravoslovje, 35, 93: Clitum cum equo ad bellum festinantem in 35, 96: Neoptolemum ex equo adversus Persas. 
v Efezu leta 322 pr. Kr. pa vse do svoje smrti leta 301 pr. Kr. gospodar Jonije. Monarha je slikar upodobil kar trikrat: v oklepu, kako stopa s konjem na povodcu (35, 96: Antigonum thoracatum cum equo incedentem), nadalje sedečega na konju v kraljevi opravi (35, 96: eundem regem sedentem in equo) in naposled v profilu, da bi prikril kraljevo "lepotno napako", kajti Antigon je imel eno oko iztaknjeno $(35,90) \cdot{ }^{34}$ Strabo $(X I V, 2,19)$ poroča, da je bila ta slika razstavljena v Asklepijevem svetišču na otoku Kosu; najverjetneje je nastala med letoma 306 in 301 pr. Kr., ko je imel Antigon I. oblast nad omenjenim otokom.

Nekateri izmed Apelovih portretov so bili naslikani skrajno naturalistično, celo do karikature $(35,88-89)$, v drugih pa je raziskoval različne osebnosti $\mathrm{z}$ vidika ilustracije raznolikih človeški tipov, na primer konjenikov, bojevnikov, svečenikov, kraljev, mestnih magistratov, tragiških igralcev itd. (35, 93 in 96). Neki grški epigram (Anthologia Palatina, IX, 595) pa pripisuje Apelu celo avtorstvo prvega antičnega avtoportreta.

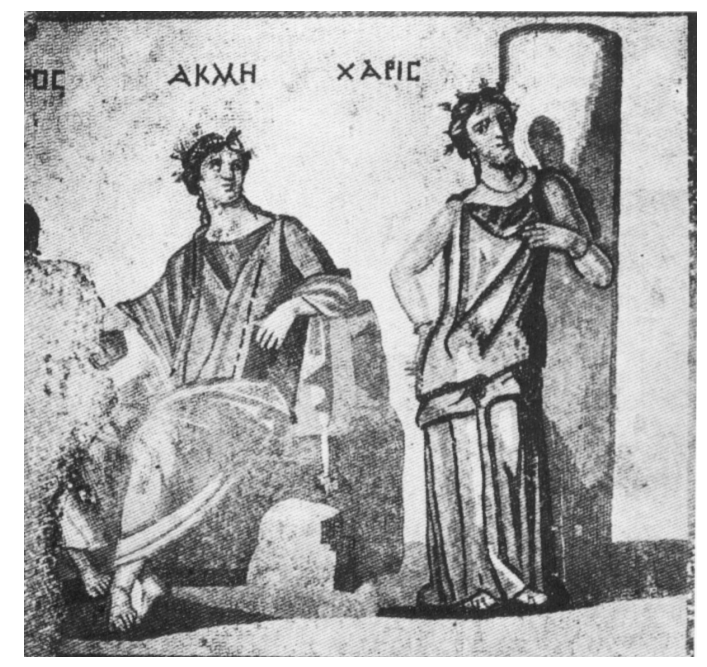

slik. 5: Akme in Haris, mozaik iz Biblosa (Beirut, Arheološki muzej). vir: Moreno (1987)

34 Plinij starejši, Naravoslovje, 35, 90: pinxit et Antigoni regis imaginem altero lumine orbati primus excogitata ratione vitia condendi; obliquam namque fecit, ut, quod deerat corpori, picturae deesse potius videretur, tantumque eam partem a facie ostendit, quam totam poterat ostendere.

Ta isti podatek prinaša tudi Kvintilijan, Izobraževanje govornika, II, 13, 12. 
Iz različnih virov izvemo za Apelove alegorične upodobitve Akme, Haris in Kairosa ter Tihe. ${ }^{35}$ Prve tri personifikacije so se ohranile na dveh mozaikih, ki izhajata iz Biblosa in Baalbeka. Na mozaiku iz Biblosa (Bejrut, Arheološki muzej; slik. 5) je Akme upodobljena sede, Haris pa stoje ob stebru, v drži boginje Afrodite. Kairos je na mozaiku iz Baalbeka (Rim, Kapitolinski muzeji; slik. 6) mladenič z Aleksandrovimi potezami. Asociacija na makedonskega kralja je bila nadvse primerna, kajti Aleksander je veljal za pravo utelešenje "ugodnega trenutka". Tihe, ki je bila prav tako kot Haris v Smirni, ni ponazarjala personifikacije mesta, kot bo pozneje v času helenizma, temveč “Srečo", ki bo v rimskih časih preimenovana v Fortuno.

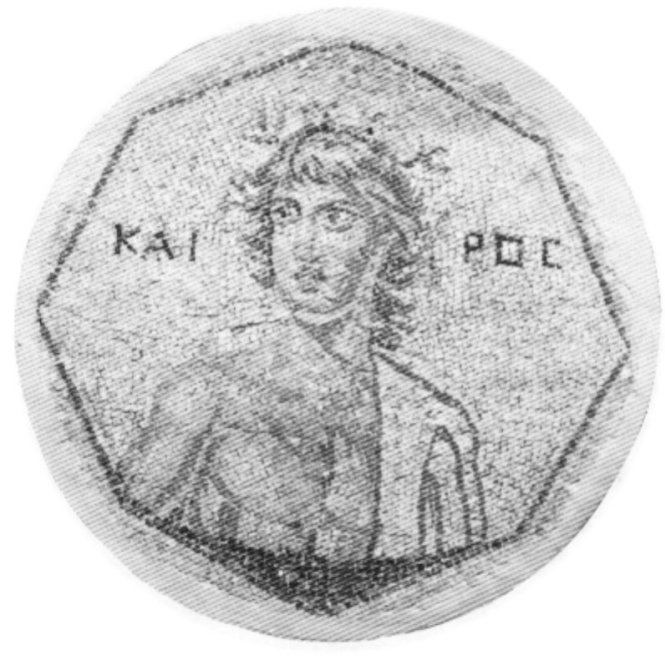

slik. 6: Kairos, mozaik iz Baalbeka (Rim, Kapitolinski muzeji). vir: Moreno (1987)

Apelova najbolj znana alegorična podoba je bila brez dvoma slika s pomenljivim latinskim naslovom Calumnia, Obrekovanje. Nastala je v času Apelovega bivanja na dvoru Ptolemaja I. v Aleksandriji, ko ga je njegov rival Antifil pri kralju po krivem obtožil, ta pa je obrekovanju naivno prisluhnil. Zadeva se je k sreči obrnila slikarju v prid in ob tej priložnosti je Apel nasli-

35 O Apelovih alegoričnih upodobitvah Kairosa, Akme in Haris poroča Pavzanias (IX, 35, 6), Tihe pa omenja Stobaj (Florilegius, CV, 60). 
kal alegorijo Obrekovanja, ki jo poznamo iz natančnega Lukijanovega opisa (Calumniae non temere credendum, 2-5): "Na desni sedi moški z dolgimi ušesi, kot bi šlo za Midasa. Proti njemu stopa personifikacija Krive obtožbe, ob njem stojita Nevednost in Sumničavost. Kriva obtožba je sicer lepega videza, toda njen obraz je zaradi jeze ves razjarjen; v levici drži gorečo baklo, z desnico vleče za lase mladega moža, ki dviga roke v nebo in kliče bogove za pričo. Vodi ga moški, ki je videti, kot bi bil sključen in bled od dolge bolezni; ta pooseblja Nevoščljivost. Še dve drugi ženski spremljata Krivo obtožbo in jo spodbujata. To sta Laž in Pretkanost. Za to stopa Ponavljanje, ki obrača glavo proti Resnici, ta pa pravkar prihaja na prizorišče."

Asklepijevo svetišče na otoku Kosu se je lahko ponašalo z dosti umetninami, toda vse je presegala Apelova Afrodita Anadyomene (Afrodita, porojena iz morske pene), ki so jo proslavili številni literarni ustvarjalci. ${ }^{36}$ Toda antični pisci si niso enotni, katera grška lepotica je Apelu pozirala kot model, Aleksandrova in pozneje Apelova ljubica Pankaspa iz Larise ali Atenčanka Frina, po kateri je domnevno nastala tudi Praksitelova Knidoška Afrodita. ${ }^{37}$ Po pričevanju Atenaja (XIII, 590 f) je bila hetera Frina izjemne lepote, tako da je bilo vsem Grkom v veselje, ko si je med elevzinskimi praznovanji in med obhajanjem Pozejdonovega praznika slekla ogrinjalo, razpustila lase in stopila v valove. Ravno ta trenutek naj bi navdahnil tudi Apela, ki je prizor ovekovečil v motivu Afroditinega rojstva iz morske pene.

Tudi ta slika se je, kot večina grških mojstrovin, znašla v Rimu. Prebivalci Kosa so, da bi poplačali ogromen dolg, sliko leta 30 pr. Kr. predali Oktavija-

36 Plinij starejši, Naravoslovje, 35, 91; preostali Reinach, 1985, str. 332-339, kat. 426-455.

Afrodita, porojena iz morske pene je bila v rimskem času najznamenitejša poznoklasična slika, bodisi zaradi kvalitet samega dela bodisi zaradi izrednega pomena, ki ga je boginja Afrodita pridobila v času helenizma. Delo je postalo znamenito tudi zaradi številnih ekfrastičnih epigramov, ki datirajo od časa zgodnjega helenizma do bizantinske dobe (od Leonidasa iz Taranta, ki je živel na prehodu iz 4. v 3. stol. pr. Kr., do Julijana iz Egipta iz 6. stol. po Kr.); med temi sta najznamenitejša epigrama, ki sta ju spesnila že omenjeni Leonidas iz Taranta in Antipater iz Sidona (Anthologia Planudea, IV, 182 in 178).

37 Plinij meni, da je kot model služila Pankaspa $(35,87)$, Atenaj pa, da jo je naslikal po Frini (XIII, 590 f). Če je za sliko pozirala Pankaspa, velja datacija po letu 334 pr. Kr. Slikar je pozneje delo odnesel s seboj na otok Kos, kjer ga je poklonil Asklepijadovemu svetišču. Mogoča je tudi uporaba več modelov, kajti absolutna lepota, ki jo pooseblja Afrodita, ni mogla biti utelešena le $\mathrm{v}$ enem samem telesu. Podoben ustvarjalni postopek zasledimo že pri Zevksisu, ki je svojo Heleno pri toaleti naslikal po najlepših krotonijskih dekletih, in pozneje pri Praksitelu, ki bo upodobil Knidoško Afrodito po heterah Frini in Kratini. 
nu in ta jo je naslednjega leta posvetil v Templju Božanskega Julija $(35,91)$. Spodnji del slike je bil takrat že poškodovan, vendar si je v Avgustovem času noben umetnik ni drznil restavrirati. Ko se je stanje v času Nerona še poslabšalo, so original zamenjali s kopijo izpod čopiča slikarja Doroteja $(35,91)$.

Apelovo šolanje v Sikionu je najbolje razvidno iz slike Herakla, ki je $s$ hrbtom obrnjen proti gledalcem (35, 94: Herculem aversum). Ta je bila v Plinijevem času v rimskem Templju Antonije mlajše, arheologi pa menijo, da je njena verodostojna kopija stenska slika iz Bazilike v Herkulaneu, ki zdaj visi v neapeljskem Nacionalnem arheološkem muzeju (slik. 7).

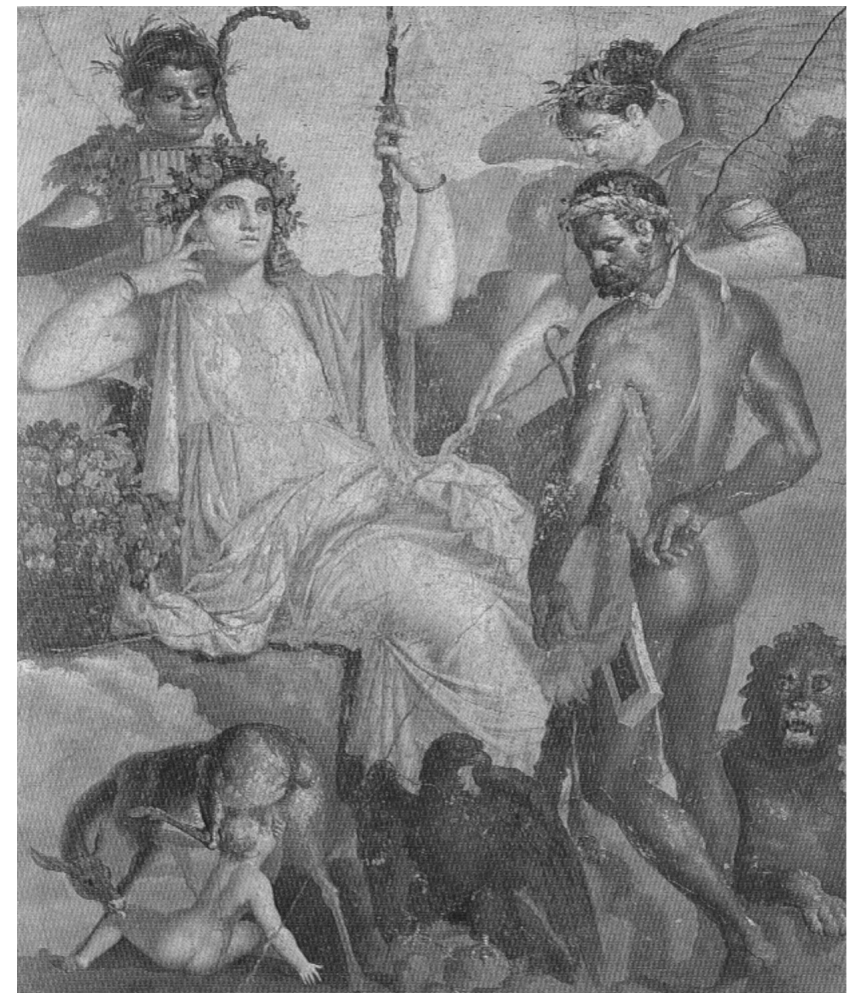

slik. 7: Herakles, ki je s hrbtom obrnjen proti gledalcem, iz Bazilike v Herkulaneu, sredina 1. stol. po Kr. (Neapelj, Nacionalni arheološki muzej). vir: Moreno (1987) 
Slika sledi strogim sikionskim pravilom kompozicije, saj jo lahko natančno razdelimo v tri plane, figure pa s svojo razporeditvijo tvorijo sekajoči se diagonali, ki oblikujeta štiri enake trikotnike.

Drugi plan v celoti zapolnjujeta sedeča personifikacija Arkadije, ki pa sega čez vse tri "pasove" - v spodnjem se začenjajo noge, trup zaseda skoraj polovico osrednjega, glava spada v zgornjega - in stoječi Herakles, ki je obrnjen s hrbtom proti gledalcem, vendar obrača svoj pogled v levo, na malega Telefa. Iz te Heraklove drže je slika dobila svoje ime.

Prvi plan "odpira" mali Telef, ki ga na gori Partenij hrani srna. Sledi orel, ki simbolizira Zevsa, Heraklovega očeta, obenem pa aludira na Zevsovo svetišče v Olimpiji. To romarsko središče leži v Elidi, pokrajini, ki meji z Arkadijo na zahodu, na vzhodni strani pa je mejna pokrajina Arkadije Argolida, na katero spominja nemejski lev v desnem kotu slike, lev, ki je obenem Heraklov atribut.

V tretjem planu sta, za nekakšno prostorsko kuliso, nad Arkadijo satir v značilni pastirski opravi (koža, piščal iz trsja, ukrivljena palica) in nad Heraklom Nike z žitnim klasjem. Zadnje najverjetneje namiguje na Heraklovo iniciacijo v Demetrine misterije. Satir in Nike, vsak na svojem koncu predstavljata vrh obeh prostorskih diagonal, ki se sekata na Arkadijinih kolenih. Ženska figura Arkadije je upodobljena v nadnaravni, skorajda kolosalni velikosti (sede je enako visoka kot Herakles), kar ponazarja goratost te osrednje grške pokrajine.

Na to sliko Plinij naveže Apelovo upodobitev Junaka v herojski goloti (35, 94: heroa nudum), ki je bil verjetno podoben Heraklovemu liku. Gre za kanonsko figuro, ki so jo upodobili tudi slikarji Zevksis, Timant in Evpomp ter kiparja Poliklejt in Lizip. ${ }^{38}$

Plinij konča slikarjev opus z nedokončano sliko Afrodite, delom za otok Kos, ki ga je prekinila umetnikova smrt, vendar si je pozneje ni drznil nihče dokončati $(35,92){ }^{39}$

38 Za vse Plinij starejši, Naravoslovje: Zevksis $(35,63)$, Timant $(36,74)$, Evpomp $(35,75)$, Poliklejt $(34,55)$, Lizip $(34,62)$.

39 Plinij starejši, Naravoslovje, 35, 92: Apelles inchoaverat et aliam Venerem Coi, superaturus etiam illam suam priorem. invidit mors peracta parte, nec qui succederet operi ad praescripta liniamenta inventus est. 
Apel je svojo slikarsko doktrino zapisal v traktatu, ki ga je posvetil učencu Perzeju, vendar se žal ni ohranil $(35,79$ in 111). Čeprav so antični viri glede Apelovih del zelo zgovorni, pa iz njih izvemo prav malo o umetnikovi slikarski tehniki in spretnosti. Plinij starejši nas pouči, da je slikar uporabljal le štiri barve $(35,50)$ ter da je iznašel nekakšen lak (atramentum), katerega skrivnost je umrla z njim $(35,97)$. Apela ne srečamo v seriji grških slikarjev iznajditeljev, je pa gotovo mojster, ki je obvladal vse dotedanje slikarsko znanje, ki ga je podkrepil z doslednimi principi sikionske šole, kar lahko spoznamo iz nekaterih njegovih del. Sikionska pravila o proporcu in kompoziciji po geometričnih načelih razberemo, na primer, iz kanonskega lika Junaka $v$ herojski goloti in razporeditve likov na sliki Herakla, ki je s hrbtom obrnjen proti gledalcem.

Da je zasnova Apelovih tabelnih slik temeljila na funkcionalni liniji, se najlepše pokaže $v$ anekdoti o slikarskem tekmovanju s Protogenom, pa tudi iz nedokončane slike Afrodite, na kateri je bila figura le zarisana z liniamenta $(35,92)$. Plinij je Apela prištel med tetrakromiste in tudi sicer je barva v Apelovem slikarstvu sekundarnega pomena. Sikionski naturalizem pa je prišel do izraza $v$ portretih, med katerimi zasledimo že prve poskuse karikature.

V Apelovem času so delovali številni izjemni umetniki in nekateri so ga - tako je menil Apel sam - v posameznih veščinah celo presegali (35, 80). Protogen mu je bil - po Apelovih besedah - enak v vsem ali celo boljši, vendar je imel eno veliko napako: svoje slike je preveč "pilil" in ni znal pravočasno "odmakniti roke od table" $(35,80)$. Apel je bil slabši od Melantija po dispoziciji figur in od Asklepiodora po perspektivični postavitvi figur v rostor $(35,80) .{ }^{40}$ Toda Apelove tabelne slike so posedovale neko izjemno kvaliteto, ki je drugje ni bilo najti, in to je charis $(35,79)$, kar bi lahko prevedli kot gracija ali ljubkost, milina. ${ }^{41}$

40 Plinij starejši, Naravoslovje, 35, 80: dixit enim omnia sibi cum illo paria esse aut illi meliora, sed uno se praestare, quod manum de tabula sciret tollere, memorabili praeceptoncere saepe nimiam diligentiam. fuit autem non minoris simplicitatis quam artis. Melanthio dispositione cedebat, Asclepiodoro de mensuris, hoc est quanto quid a quoque distare deberet.

41 Plinij starejši, Naravoslovje, 35, 79: praecipua eius in arte venustas fuit, cum eadem aetate maximi pictores essent; quorum opera cum admiraretur, omnibus conlaudatis deesse illam suam venerem dicebat, quam Graeci xarita vocant; cetera omnia contigisse, sed hac sola sibi 
Apelova dela so v antiki veljala za mojstrovine neprecenljive vrednoti. $\mathrm{O}$ tem nas prepriča bodisi dejstvo, da jih je cesar Avgust razstavil v najbolj reprezentativnih spomenikih svojega, obnovljenega Rima, bodisi podatek, da so tako rekoč vsi antični pisci, ne le Plinij starejši, ko so govorili o vrhuncu v slikarstvu, vedno navedli ravno Apela.

\section{LITERATURA}

Bianchi Bandinelli, R., La pittura antica, Rim, 1980.

Bruno, V. J., Form and Color in Greek Painting, New York, 1977.

Coarelli, F. in drugi, Artisti e artigiani in Grecia, Rim, Bari, 1980.

Gage, J., A locus classicus of color theory. The Fortunes of Apeles, Journal of the Warburg and Courtauld Institutes, 44 (1981), str. 1-26.

Gaio Plinio Secondo, Storia naturale, V. Mineralogia e storia dellarte. Libri 33-37 (prevod in komentar Corso, A., Mugellesi, R., Rosati, G.), Torino, 1988.

Giuliano, A., Storia dellarte greca, Roma, 20025.

Gualandi, M. L., L'antichità classica, Roma, 2001 (Le fonti per la storia dell'arte, 1).

Keuls, E. C., Plato and Greek Painting, Leiden, 1978.

Moreno, P., Kairós, Akmé e Cháris da una pittura di Apelle, Dialoghi di Architettura, 2 (1984), str. 115-118.

Moreno, P., Pittura greca. Da Polignoto a Apelle, Milano, 1987.

Panofsky, E., Die Perspektive als "symbolische Form", v: Vorträge der Bibliothek Warburg 1924-1925 (ur. Saxl, F.), Leipzig, Berlin, 1927, str. 258-330.

neminem parem.

Bistvo umetniškega dela torej ni v znanstveno-tehnični osnovi (ars ali technike) in v izvežbanosti čopiča (praxis), do katerih se lahko pride s študijem in vajo, ampak v prirojeni nadarjenosti (ingenium). 
Pemberton, E. G., A Note on Skiagraphia, American Journal of Arcaeology, 80 (1976), str. 81-84.

Pittura e pittori nellantichità, Rim, 1968 (separat iz Enciclopedia dellarte antica classica e orientale, I-VII, Rim, 1958-1966).

Pollitt, J. J., The ethos of Polygnotus and Aristides, v: In memoriam Otto Brendel. Essays in Archaeology and the Humanities (ur. Bonfante, L., in von Heintze, H.), Mainz, 1976, str. 49-54.

Reinach, A., Textes Grecs et Latins relatifs à l'histoire de la peinture ancienne, Pariz, 1921 (ponovna izdaja Pariz, 1985: uvodna študija in komentar Rouveret, A.).

Richter, G. M. A., Perspective in Greek and Roman Art, London, New York, 1970.

Robertson, M., La peinture greque, Ženeva, $1978^{2}$.

White, J., Perspective in Ancient Drawings and Painting, London, 1956. 


\section{PLINY THE ELDER ON GREEK PAINTING AND ITS MOST IMPORTANT REPRESENTATIVE, APELLES OF COLOPHON}

Keywords: Pliny the Elder, Naturalis Historia, art history sources, Greek painting, Apelles of Colophon, Alexander the Great

\section{Abstract}

In his encyclopedic Naturalis Historia, Pliny the Elder dedicated most of his attention among all art forms to Greek painting (35, 2-150), from which it can be concluded that painting was highly valued among the Greeks and most likely considered the most prestigious form of fine arts. Because almost all Greek painting originals and art history essays from the Classical and Hellenistic periods have been lost, Pliny's history of ancient art is of exceptional importance because the author was well acquainted with the production of both.

According to Pliny, painting was invented by the Greeks (and not the Egyptians) in Sicyon or Corinth, when they drew a line around the contours of a human shadow. At the end of the Archaic Period and especially during the Classical Period, Greek painters were moving increasingly closer to realism, especially in depicting human figures. However, for the development of painting as an art form a series of exclusively Greek innovations was of great importance; these followed one another from the end of the 6th century BC to the late Classical Period. According to Eva Keuls (1978), the most important among these are the following: catagraphy or slanting images (Gr. katagraphia, Lat. imagines obliquae) invented by Cimon of Cleonae (end of 6th century BC), scene painting (Gr. skenographia, no specific Latin term) introduced by Agatharchus of Samos (460-420 BC), shading (Gr. skiagraphia, Lat. lumen et umbrae) invented by Appolodorus of Athens (430-400 BC) and Zeuxis of Heraclea (425-397 BC), and painting of ethos and pathos (Gr. ethe and pathos, Lat. mores and perturbationes), which is said to have been introduced by Aristeides II of Thebes (360-310 BC). 
In the 4th century $\mathrm{BC}$, the primacy in painting was shared by the older Sicyon school and the younger Theban-Attic school. The Sicyon school is important for two reasons. First, it succeeded in including painting in the Greek Paidea and raising it to the level of artes liberales. Second, it trained the greatest Greek painter, Apelles of Colophon (360-300 BC). In addition to their technical perfection, the Theban-Attic masters are also important because they were the only Greek painters to whom original paintings can be ascribed: Nicomachus of Thebes (390-340 BC) painted the frescos on Persephone's tomb in the Macedonian town of Vergina, and Nicias of Athens (350-300 BC) painted the frieze on the facade of Philip II of Macedon's tomb at Vergina. At the same time, archeologists believe that Philoxenus of Eretria (350-300 BC) was the author of the painting that was copied in the famous Alexander Mosaic depicting Alexander's battle against Darius III of Persia, located at the House of the Faun in the ruins of Pompeii (displayed at the National Archeological Museum in Naples).

Pliny the Elder fully agrees with other Greek and Roman authors that Apelles of Colophon was the most important ancient painter. This is why he dedicates nineteen chapters $(35,79-97)$ to Apelles in his overview. Through anecdotes about the artist's life and work, he also provides information on the painter's character and gives a detailed description of his oeuvre. Of great importance for both Hellenistic and later Roman art were his portraits of Alexander the Great, especially the image of Alexander Keraunophoros (Alexander the Great holding a Thunderbolt) for the temple of Artemis in Ephesus, which represents an important innovation in ruler iconography because Alexander is depicted with divine attributes. The image of victorious Alexander has been preserved in two paintings (Castor and Pollux with Victory and Alexander the Great and War with the Hands Tied behind, with Alexander riding in Triumph in his Chariot) that Augustus put on display at his Forum in Rome. More notable among Apelles' portraits of famous persons is his portrait of Antigonus I Monophthalmus, whom he painted in profile to conceal his disfigurement (he only had one eye). Among his allegorical depictions, the picture of Calumny, which was based on a true episode from the artist's life, has been preserved in historical memory. Compositional principles of the Sicyon school can be seen in his depiction of Heracles with Face Averted. 
Since the Hellenistic Period, Apelles' most famous picture has been Aphrodite Anadyomene (Aphrodite Rising from the Sea), for which Apelles used his mistress Pancaspe of Larissa as his model for Aphrodite; another legend has it that it was inspired by the famous hetaera, the courtesan $\mathrm{Ph}$ ryne of Athens. The only work that could be said to be more famous is the unfinished painting of Aphrodite of Kos, which was left unfinished due to the artist's death. 